УДК 598.9(571.63)

dx.doi.org/10.24866/7444-4911-7/5-7

\title{
Первый случай гнездования большеклювой вороны Corvusmacrorhynchos в центральной застройке Уссурийска (Приморский край)
}

\author{
Ю.Н. Глущенко
}

Дальневосточный федеральный университет. Филиал в г. Уссурийске (Школа педагогики) Тихоокеанский институт географии ДВО РАН (г. Владивосток)

В публикации приводится первый случай гнездования большеклювой вороны в центральной застройке г. Уссурийска (Приморский край).

Ключевые слова: Приморский край, г. Уссурийск, большеклювая ворона, Corvusmacrorhynchos, урбанистический ландшафт, гнездование.

Большеклювая ворона (CorvusmacrorhynchosWagler, 1827) является политипическим видом, широко распространённым на востоке Азии. На Дальнем Востоке России встречается два подвида этой вороны - японский (C. m. japonensisBonaparte 1850) и маньчжурский (C. m. mandshuricusButurlin, 1913). Первый из них занимает исключительно островную часть российского сектора ареала, а второй относится к обычным гнездящимся, кочующим и зимующим птицам Приморского края. В типичном случае большеклювая ворона населяет здесь различные варианты лесных биотопов на равнинах и в горах, а также морское побережье и острова Японского моря. В отличие от японского подвида, который в различных регионах издавна активно заселял урбанистический ландшафт, она в меньшей степени тяготеет к гнездованию в населённых пунктах, а по некоторым данным, собранным на Ханкайско-Раздольненской равнине в последней четверти прошлого века (Тарасов, 1993), вовсе избегает гнездиться в них.

На Северном Сахалине маньчжурский подвид большеклювой вороны в гнездовой период начал активно осваивать населённые пункты в 1980-х гг. (Нечаев, 1991). В Нижнем Приамурье первое гнездо было найдено в г. Комсомольске-на-Амуре в 1996 г. (Бабенко, 2000). Из городов Приморья эта форма первым начала заселять Владивосток, причём в 1959-1964 гг. она не входила в состав гнездящихся видов упомянутого города (Назаров, 1965). К середине 1980-х гг. она уже гнездилась здесь, но в небольшом количестве (Назаров, Казыханова, 1986). В 1991 г. в черте этого города гнездилось около 150 пар (Назаров, 2004), а в текущем столетии, по нашим данным, она здесь вполне обычна. Не исключено, что примерно в тот же период эта ворона начала заселять и другой прибрежный город Приморья - Находку, в центральных районах которого плотность населения данного вида в первой половине июля 2005 г. достигла 66,8 особей/км² (Глущенко, Липатова, 2005).

В окрестностях Уссурийска большеклювая ворона является малочисленным гнездящимся, обычным кочующим и зимующий видом, который гнездится здесь как в примыкающим к городской черте сопковых дубняках, так и в речных долинах при наличии старых лесопосадок или возвышенных участков уремы с многопородными лесными островками с крупными деревьями (Глущенко и др., 2019). В центральной застройке этого города до последнего времени эта ворона не гнездилась, посещая её летом случайно при суточных трофических перемещениях, так, в 2002-2004 гг. плотность её населения в этом типе местообитаний составляла лишь около 0,1 особей/км² (Глущенко и др., 2006).

Впервые строительство гнезда большеклювой вороны в центральной части Уссурийска 
было зарегистрировано 7 апреля 2018 г. на пересечении ул. Пушкина и Некрасова примерно в 100 м от центральной площади города. Гнездо размещалось в предвершинной части ильма, растущего на придорожном газоне и сохранялось в течение двух последующих лет (см. рис.).

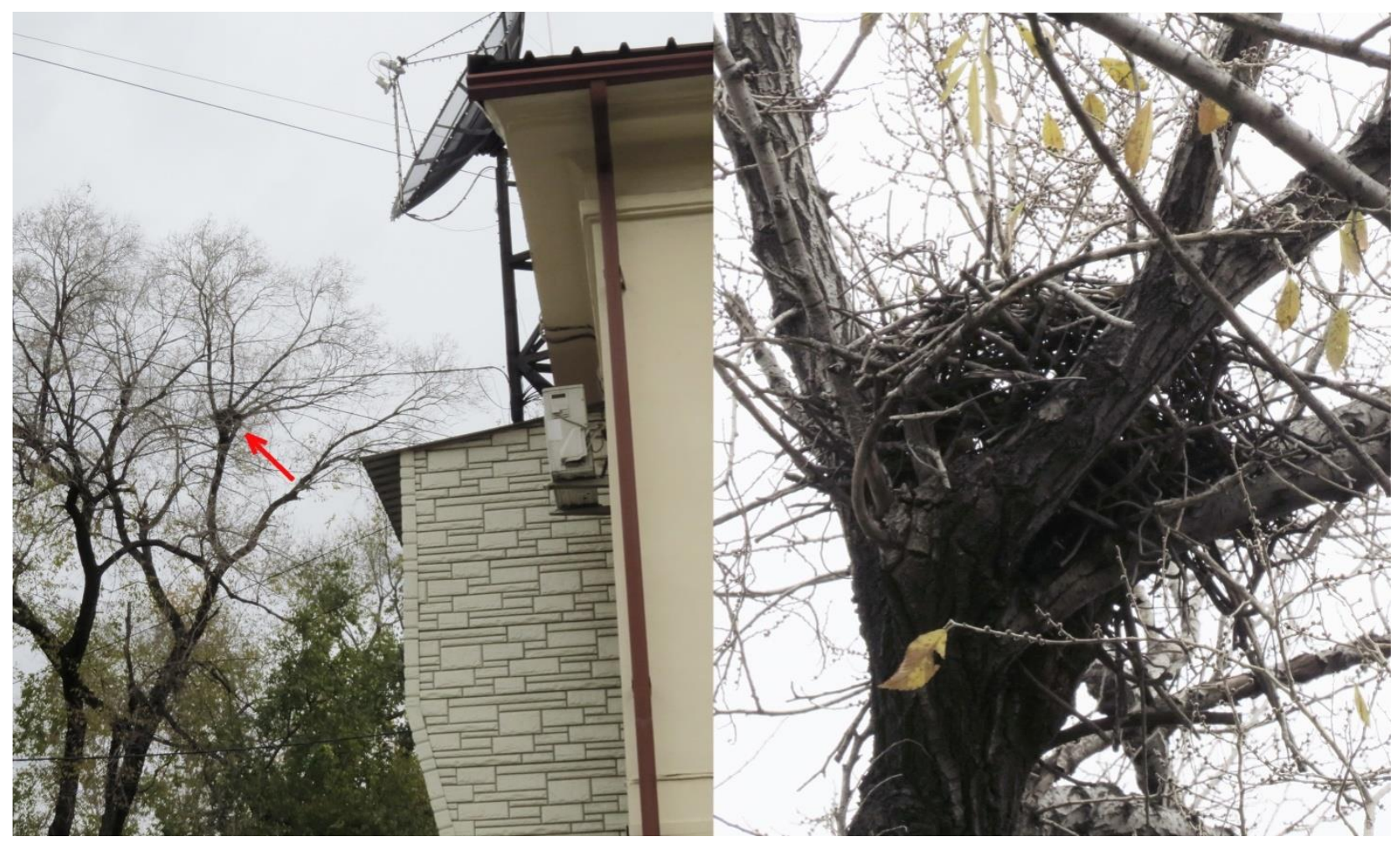

Гнездо большеклювой вороны Corvusmacrorhynchos, расположенное в центральной застройке г. Уссурийска. 21 октября 2020 г., фрото автора.

\section{Литература}

Бабенко В.Г. Птицы Нижнего Приамурья. Монография. М., 2000. 724 с.

Глущенко Ю.Н., Коробов Д.В., Харченко В.А., Коробова И.Н., Глущенко В.П. Птицы - Aves // Природный комплекс Уссурийского городского округа; современное состояние. Владивосток: ДВФУ, 2019. С. $151-301$.

Глущенко Ю.Н., Липатова Н.Н. Летнее население птиц некоторых городов юга Дальнего Востока России // Животный и растительный мир Дальнего Востока. Вып. 9. Уссурийск: УГПИ, 2005. C. 82-89.

Глущенко Ю.Н., Липатова Н.Н., Мартыненко А.Б. Птицы города Уссурийска: фрауна и динамика населения. Владивосток, 2006. 264 с.

Назаров Ю.Н. К фрауне птиц Владивостока // Тез.докл. и сообщ. на секции общественных наук 8-й Дальневост. конф. молодых специалистов. Владивосток, 1965. С. 109-110.

Назаров Ю.Н. Птицы города Владивостока и его окрестностей. Владивосток, 2004. 276 с.

Назаров Ю.Н., Казыханова М.Г. Летняя фауна Владивостока // Изучение птиц СССР, их охрана и рациональное использование. Тез.докл. 1-го съезда Всесоюз. орнитол. конф. Л., 1986. Ч. 2. С. 99 100.

Нечаев В.А. Птицы острова Сахалин. Владивосток, 1991. 748 с.

Тарасов А.А. К экологии большеклювой вороны в Приморском крае // VIIAрсеньевские чтения. Уссурийск: УГПИ, 1993. С. 17-19. 


\section{The first case of nesting of the Large-billed Crow Corvusmacrorhynchos in the central part of Ussuriyskcity(Primorsky Territory)}

\section{Yu.N. Gluschenko}

\section{Far Eastern Federal University. Branch in the Ussuryisk city (School of pedagogics) \\ Pacific Geographical Institute FEB RAS (Vladivostok)}

The publication presents the first case of a Large-billed Crow nesting in the central part ofUssuriisk (Primorsky Territory).

Keywords: Primorsky Territory, Ussuriisk, Large-billed Crow, Corvusmacrorhynchos, nesting, urban landscape.

\section{Сведения об авторах:}

Глущенко Юрий Николаевич - кандидат биологических наук, доцент кафедры естественнонаучного образования филиала ДВФУ в г. Уссурийске (Школы педагогики). 692500, Приморский край, г. Уссурийск, ул. Некрасова,35; ведущий научный сотрудник лаборатории экологии и охраны животных Тихоокеанского института географии ДВО РАН. 690041, Приморский край, е. Владивосток, ул. Радио, д. 7. E-mail: yu.gluschenko@mail.ru; 